\title{
MORPHOPHYSIOLOGICAL ADAPTATIONS OF THE GASTROINTESTINAL TRACT IN PIGLETS FED A SESAME MEAL OR SOYBEAN MEAL DIET
}

\author{
${ }^{1}$ Araceli Aguilera Barreyro, ${ }^{1}$ Tércia Reis de Souza, \\ ${ }^{2}$ Gerardo Mariscal-Landín, ${ }^{1}$ Guerrero Carrillo María de Jesús, \\ ${ }^{1}$ Konisgmar Escobar García, ${ }^{1}$ Guadalupe Bernal Santos and ${ }^{1}$ Teresa García Gasca \\ ${ }^{1}$ Posgrado en Ciencias Biológicas, Facultad de Ciencias Naturales, Universidad Autónoma de Querétaro Av. \\ de las Ciencias s/n, Juriquilla, 76230, Querétaro, Querétaro, México \\ ${ }^{2}$ Centro Nacional de Investigación en Fisiología Animal, Instituto Nacional de Investigaciones Forestales, \\ Agrícolas y Pecuarias, km 1, Carretera a Colón, Ajuchitlan Colón, Querétaro, 76280. México
}

Received 2013-12-06; Revised 2014-01-10; Accepted 2014-01-11

\begin{abstract}
An important indicator to recommend a protein source for piglet nutrition is the absence of intestinal damage. The effects of sesame or soybean meal based diets on Gastrointestinal Tract (GIT) morphophysiology, diarrhea incidence and severity in piglets were studied during the first two weeks postweaning. Thirty-six piglets weaned at 21 days of age were fed one of three diets: A control casein diet (C), a Sesame Meal diet (SM), or a Soybean Meal Diet (SBM). Diarrhea incidence and fecal score were determined once daily over a 14-day period. After 14 days, 3 piglets in each experimental group were fasted $12 \mathrm{~h}$, fed for 1 hour and then slaughtered at 3, 6, 9 and $12 \mathrm{~h}$ after feeding, at which times relative GIT

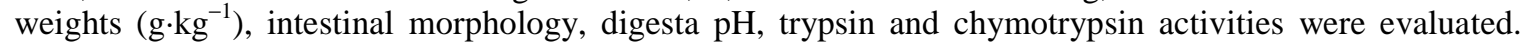
Stomach and small intestine weight were higher $(\mathrm{p}<0.05)$ in piglets fed SBM and SM than in piglets fed C. The gastric $\mathrm{pH}$ was higher in piglets fed $\mathrm{C}$ and $\mathrm{SM}$ and lower in piglets fed SBM $(\mathrm{p}<0.05)$. The $\mathrm{pH}$ of the different segments of the GIT was not affected $(p>0.05)$ by dietary protein source. The specific activity of chymotrypsin was higher $(\mathrm{p}<0.05)$ in animals fed $\mathrm{C}$ than in those fed SM and SBM and did not vary with after feeding time $(\mathrm{p}>0.05)$. Trypsin activity was higher $(\mathrm{p}<0.05)$ in piglets fed SBM than those fed $\mathrm{C}$ and SM. The dietary protein source had no impact $(\mathrm{p}<0.05)$ on villus height or duodenal and ileal crypt depth. Jejunal villi in piglets fed SBM were shorter $(\mathrm{p}<0.05)$ than in piglets fed C and SM. Dietary treatment had no effect on diarrhea incidence and severity. These findings show that sesame meal can replace soybean meal as a protein source in starter diets for weaned piglets.
\end{abstract}

Keywords: Villi Morphology, Sesame Meal, Soybean Meal, Digestive Enzymes, Piglets

\section{INTRODUCTION}

At weaning, piglets experience a period of underfeeding and diarrhea caused by the stress of separation from the sow, changing facilities and diet changes (Vente-Spreeuwenberg et al., 2001). The lowered feed intake and gastrointestinal tract development observed during weaning have been associated with diet ingredients (Lallès et al., 2007), particularly the presence of Anti-Nutritional Factors (ANFs), as well as the quantity and type of fiber in vegetable protein sources (Hermes et al., 2009). Soybean meal is the main vegetable protein source used in piglet diets because of its amino acid profile; however, it contains ANFs that may limit its use (Makkink et al., 1994; Palacios et al., 2004). Sesame meal is an alternative to soybean meal that can be used in starter diets; its high protein content and low ANF levels are

Universidad Autónoma de Querétaro Av. de las Ciencias s/n, Juriquilla, 76230, Querétaro, Querétaro, México 
attractive, but its phytic acid concentration may prove problematic (Jimoh et al., 2011) and there is little information about its use in piglet diets. The present study evaluates the effect of sesame and soybean meal starter diets in weaned piglets on gastrointestinal tract weight, villi height, intestinal crypt depth, gastric and intestinal digesta $\mathrm{pH}$ (duodenum, jejunum and ileum) and trypsin and chymotrypsin activities.

\section{MATERIALS AND METHODS}

Procedures were conducted at the CENID-Physiology experimental farm, according to the guidelines established in the Mexican Official Norm NOM-062ZOO-1999 for production, care and use of laboratory animals (DOF, 2001) and the guidelines of the International Guiding Principles for Biomedical Research Involving Animals (CIOMS, 1985).

\subsection{Ingredients and Chemical Composition of Experimental Diets}

The chemical composition of the sesame and soybean meals used in experimental diets is described in Table 1. Sesame meal showed a higher content of the following nutrients compared to soybean meal: Crude protein, ether extract, neutral detergent fiber, combined methionine and cysteine, arginine and phytic acid. Soybean meal showed a higher lysine content and a higher Trypsin Inhibitor Activity (TIA) compared to sesame meal.

Three diets were formulated: Casein diet (C) (used as a reference protein), Sesame Meal diet (SM) and Soybean Meal diet (SBM) (Table 2). Antibiotics were not used in any of the diets offered. The SBM diet contained 20\% soybean meal (Friesen et al., 1993). In the SM diet, adequate sesame meal was added to ensure a protein level equal to that in the SBM diet. In the SBM and SM diets, casein was supplemented to provide an adequate amount of protein and a complete amino acid profile, as recommended by the NRC (1998). Vitamins and minerals were supplemented in all diets based on requirements recommended by the NRC (1998).

\subsection{Animals and Experimental Management}

A total of 36 Fertilis $20 \times \mathrm{G}$ Performance piglets (Genetiporc) (Body Weight [BW], $7.1 \pm 0.5 \mathrm{~kg}$ ) weaned at $21 \pm 0.8$ days were used. Animals were randomly assigned to one of three experimental diets, comprising 12 piglets per experimental group. Within each experimental group, piglets were allocated into two pens based on BW, comprising 6 piglets each.
Each elevated pen was equipped with 6 manual feeding spaces, a nipple water dispenser and a plasticcovered expanded metal floor. Diets and water were available ad libitum. All piglets were weighed individually at weaning and at day 14 . Fecal consistency was visually examined daily for 14 days after weaning to determine the fecal score and diarrhea incidence. Fecal score was determined using the following scoring criteria: 0 (normal), 1 (soft feces), 2 (mild diarrhea), or 3 (severe diarrhea) (Opapeju et al., 2009). The mean fecal consistency was calculated for each experimental group based on the measured fecal scores (Reis de Souza et al., 2010). The diarrhea incidence was calculated based on the mean proportion of days that diarrhea was observed relative to the total experimental period.

On day 13 at $1900 \mathrm{~h}$ feed was removed. On day 14 at $0700 \mathrm{~h}$ all piglets were fed during one hour. Then three piglets per treatment were slaughtered at 3, 6, 9 and $12 \mathrm{~h}$ after feeding. Piglets of all groups were stunned using $\mathrm{CO}_{2}$ and euthanized by exanguination by severing the jugular vein.

A midline incision was made in the abdomen to expose the digestive tract. The stomach and small intestine were tied at the proximal and distal ends, removed from the abdominal cavity, emptied and weighed. The small intestine was removed from the abdominal cavity and divided into duodenum, jejunum and ileum. The pancreas was then excised, dissected from connective tissue, weighed, frozen immediately in liquid nitrogen and stored at $-80^{\circ} \mathrm{C}$. The organ weight was reported as a proportion of BW (relative weight, $\mathrm{g} \cdot \mathrm{kg}^{-1}$ ).

\subsection{Laboratory Analysis}

Dry Matter (DM), Crude Protein (CP) and Ether Extract (EE) were determined for each individual feed ingredient (casein, sesame meal and soybean meal) and for each diet (C, SM and SBM), according to AOAC (2000) methods 934.01, 976.05 and 920.39 respectively. The Neutral Detergent Fiber (NDF) level was measured according to the method described by Van Soest et al. (1991). Samples were prepared for amino acid determination according to method 994.12 in the AOAC (2000). Samples were hydrolyzed at $110^{\circ} \mathrm{C}$ for $24 \mathrm{~h}$ in $6 \mathrm{M} \mathrm{HCl}$. To measure the methionine and cysteine component, oxidation using performic acid was performed, followed by amino acid analysis using reverse phase chromatography on a Hewlett Packard, model 1100 HPLC apparatus, as described by Henderson et al. (2000). Trypsin Inhibitor Activity (TIA) was measured as described by Kakade et al. (1974) and phytic acid concentration was determined as recommended by Vaintraub and Lapteva (1988). 
Table 1. Chemical composition of raw materials (\% DM)

\begin{tabular}{|c|c|c|c|}
\hline \multirow[b]{2}{*}{ Chemical composition } & \multicolumn{3}{|c|}{ Raw materials } \\
\hline & Casein & Sesame meal & Soybean meal \\
\hline $\mathrm{CP}(\% \mathrm{~N} \times 6.25), \%$ & 90.3 & 53.5 & 41.6 \\
\hline $\mathrm{EE}, \%$ & - & 11.1 & 1.2 \\
\hline NDF, $\%$ & - & 17.5 & 14.5 \\
\hline TIA, mg TIA $100 \mathrm{~g}^{-1}$ & - & 100.0 & 480.0 \\
\hline Phytic acid, g sodium phytate $100 \mathrm{~g}^{-1}$ & - & 4.0 & 2.4 \\
\hline \multicolumn{4}{|l|}{ Indispensable AA } \\
\hline Arg & 3.2 & 4.9 & 3.3 \\
\hline His & 2.2 & 1.0 & 1.2 \\
\hline Ile & 4.9 & 1.5 & 2.1 \\
\hline Leu & 8.4 & 2.8 & 3.3 \\
\hline Lys & 6.1 & 1.0 & 2.7 \\
\hline Met + Cys & 3.1 & 2.1 & 1.3 \\
\hline Phe & 4.4 & 1.8 & 2.3 \\
\hline Thr & 4.2 & 1.5 & 1.7 \\
\hline Val & 6.5 & 1.9 & 2.1 \\
\hline \multicolumn{4}{|l|}{ Dispensable AA } \\
\hline Ala & 2.6 & 1.9 & 1.9 \\
\hline Asp & 6.4 & 3.6 & 5.9 \\
\hline Glu & 20.8 & 7.5 & 9.5 \\
\hline Gly & 1.5 & 2.1 & 2.2 \\
\hline Pro & 9.2 & 1.6 & 3.8 \\
\hline Ser & 4.8 & 1.9 & 2.2 \\
\hline Tyr & 4.8 & 1.6 & 1.6 \\
\hline
\end{tabular}

Table 2. Composition of experimental diets (\% DM)

\begin{tabular}{|c|c|c|c|}
\hline \multirow[b]{2}{*}{ Ingredient } & \multicolumn{3}{|c|}{ Experimental diets* } \\
\hline & $\mathrm{C}$ & SM & SBM \\
\hline Corn starch & 47.98 & 42.11 & 37.43 \\
\hline $\mathrm{CFC} \dagger$ & 4.90 & 4.00 & 4.00 \\
\hline Soybean meal & - & - & 20.00 \\
\hline Sesame meal & - & 17.45 & - \\
\hline Casein & 24.04 & 14.40 & 14.40 \\
\hline Corn oil & 5.40 & 4.00 & 5.62 \\
\hline Lactose & 12.60 & 12.60 & 12.60 \\
\hline Salt & 0.50 & 0.50 & 0.50 \\
\hline Calcium carbonate & 0.40 & 0.40 & 0.40 \\
\hline Dicalcium phosphate & 3.60 & 2.98 & 3.50 \\
\hline Mineral premix & 0.12 & 0.12 & 0.12 \\
\hline Vitamin premix $\bullet$ & 0.36 & 0.36 & 0.36 \\
\hline Gustor $^{\mathrm{TM}}$ & 0.20 & 0.20 & 0.20 \\
\hline AminoGut & 0.80 & 0.80 & 0.80 \\
\hline L-Lysine & - & 0.39 & - \\
\hline \multicolumn{4}{|l|}{ Chemical composition } \\
\hline $\mathrm{CP}(\% \mathrm{~N} \times 6.25), \%$ & 20.00 & 20.50 & 21.70 \\
\hline $\mathrm{EE}, \%$ & 6.60 & 7.70 & 8.60 \\
\hline NDF, \% & 4.60 & 8.20 & 5.60 \\
\hline TIA, mg TIA $100 \mathrm{~g}^{-1}$, & - & 17.45 & 96.00 \\
\hline Phytic acid, g sodium phytate $100 \mathrm{~g}^{-1}$, & - & 0.70 & 0.48 \\
\hline \multicolumn{4}{|c|}{ 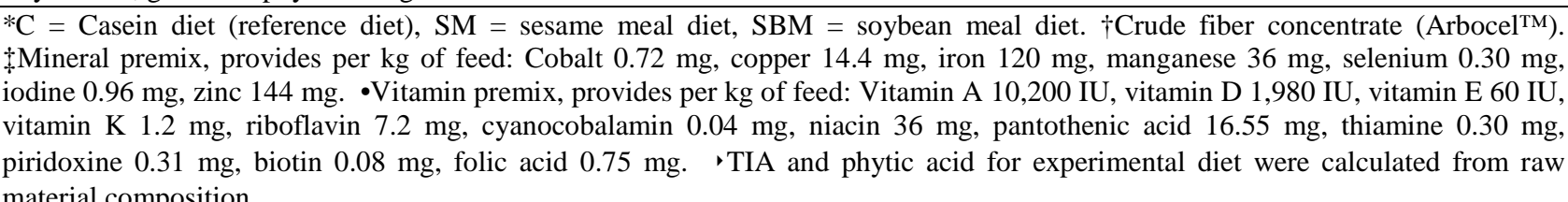 } \\
\hline
\end{tabular}


Digesta $\mathrm{pH}$ of the stomach, duodenum, jejunum and ileum was measured directly using a $\mathrm{pH}$ meter with a glass electrode. Pancreatic trypsin (EC 3.4.21.4) activity was determined using Benzoyl-Arginine-Ethyl Ester (BAEE, Sigma ${ }^{\mathrm{TM}}$ B4500) as a substrate (Reboud et al., 1962) and the chymotrypsin (EC 3.4.21.1) activity was determined using Benzoyl-L-Tyrosine-Ethyl Ester (BTEE, Sigma ${ }^{\mathrm{TM}}$ B6125) as a substrate (Hummel, 1959). Pancreatic protein concentration was determined using the Micro Lowry kit Onishi and Barr modification (Sigma $^{\text {TM }}$ TP02000) to report the specific activity of trypsin and chymotrypsin (IU.mg protein ${ }^{-1}$ ).

Intestinal villus height and Lieberkühn crypt depth were measured in piglets slaughtered at $12 \mathrm{~h}$ after feeding, using $10 \mathrm{~cm}$ portions of the duodenum, jejunum and ileum. The samples were fixed in neutral buffered formaldehyde, embedded in paraffin and sectioned into 4 $\mu \mathrm{m}$ slices. The sections were stained with hematoxylin and eosin (Nabuurs et al., 1993).

\subsection{Statistical Analysis}

Statistical analyses were performed using the GLM procedures of SAS (2008) for a completely randomized design. Enzymatic activity and $\mathrm{pH}$ data were subjected to a $3 \times 4$ factorial analysis (3 diets and $4 \mathrm{~h}$ after feeding). Relative organ weights, villus height, intestinal crypt depth, diarrhea incidence and fecal score data were analyzed as a completely randomized design with type of diet as the main effect. Differences between means were determined using a Tukey test at a 5\% significance level (Steel et al., 1997).

\section{RESULTS}

As shown in Table 3, protein source did not affect pancreatic weight $(p>0.05)$, but the stomach and small intestine weights were higher in piglets fed SM and SBM than in those fed a $\mathrm{C}$ diet $(\mathrm{p}<0.05)$.

Gastric digesta $\mathrm{pH}$ was higher $(\mathrm{p}<0.05)$ in piglets fed $\mathrm{C}$ than in those fed SBM, but no difference was observed among animals fed SM and SBM ( $p>0.05)$ (Table 4). Small intestine digesta $\mathrm{pH}$ was not affected by protein source. Gastric and ileal digesta $\mathrm{pH}$ did not vary over time in the hours after feeding $(\mathrm{p}>0.05)$, but duodenal and jejunal digestas $\mathrm{pH}$ increase between 3 and $12 \mathrm{~h}$ after feeding $(\mathrm{p}<0.05)$.

Chymotrypsin activity was higher $(\mathrm{p}<0.05)$ in animals fed the $\mathrm{C}$ diet than in those fed the SM and SBM diets (Table 4), regardless of time after feeding ( $p>0.05$ ). Trypsin activity was higher $\mathrm{p}<0.05$ ) in animals fed SBM than in those fed $\mathrm{C}$ and $\mathrm{SM}$ diets. Trypsin activity decreased $(\mathrm{p}<0.05)$ between 3 and $9 \mathrm{~h}$ after feeding and then increased at $12 \mathrm{~h}$ after feeding.

Table 3. Relative weight of digestive organs of piglets fed with C, SM and SBM diets

\begin{tabular}{|c|c|c|c|c|c|}
\hline \multirow[b]{2}{*}{ Relative weight, $\mathrm{g} \cdot \mathrm{kg}^{-1} \mathrm{BW}$} & \multicolumn{3}{|c|}{ Experimental diets* } & \multirow[b]{2}{*}{$\mathrm{p}<$} & \multirow[b]{2}{*}{ SEM } \\
\hline & $\mathrm{C}$ & SM & SBM & & \\
\hline Pancreas & 1.5 & 1.7 & 1.6 & NS & 0.04 \\
\hline Stomach & $6.2^{\mathrm{a}}$ & $7.3^{\mathrm{b}}$ & $7.1^{\mathrm{b}}$ & 0.05 & 0.15 \\
\hline Small intestine & $40.8^{\mathrm{a}}$ & $52.7^{\mathrm{b}}$ & $49.7^{\mathrm{b}}$ & 0.001 & 0.88 \\
\hline
\end{tabular}

${ }^{*} \mathrm{C}=$ Casein diet (reference diet), SM = Sesame Meal diet, SBM = Soybean Meal diet. SEM = Standard Error of Mean ${ }^{\text {ab }}$ Values in the same row with different superscripts are significantly different $(\mathrm{p}<0.05)$. NS $=$ Non Significant

Table 4. Digestive content $\mathrm{pH}$ and specific activity of pancreatic trypsin and chymotrypsin of piglets fed with C, SM and SBM diets in different hours after feedings

\begin{tabular}{|c|c|c|c|c|c|c|c|c|c|c|c|}
\hline \multirow[b]{2}{*}{ Digestive content $\mathbf{p H}$} & \multicolumn{3}{|c|}{ Experimental diets* } & \multicolumn{4}{|c|}{ Hours after feeding } & \multicolumn{4}{|l|}{$\mathrm{p}<$} \\
\hline & $\mathrm{C}$ & $\mathrm{SM}$ & SBM & 3 & 6 & 9 & 12 & $\mathrm{D}$ & $\mathrm{H}$ & $\mathrm{D} * \mathrm{H}$ & SEM \\
\hline Stomach & $3.8^{\mathrm{a}}$ & $3.5^{\mathrm{ab}}$ & $2.5^{\mathrm{b}}$ & 3.1 & 3.1 & 3.3 & 3.8 & 0.05 & NS & NS & 0.17 \\
\hline Duodenum & 5.9 & 5.8 & 5.6 & $5.1^{\mathrm{B}}$ & $5.9^{\mathrm{AC}}$ & $5.5^{\mathrm{BC}}$ & $6.6^{\mathrm{A}}$ & NS & 0.01 & NS & 0.13 \\
\hline Jejunum & 5.9 & 6.1 & 6 & $5.5^{\mathrm{B}}$ & $5.9^{\mathrm{B}}$ & $6.0^{\mathrm{B}}$ & $6.6^{\mathrm{A}}$ & NS & 0.01 & NS & 0.10 \\
\hline Ileum & 6.4 & 6.6 & 6.7 & 6.4 & 6.8 & 6.6 & 6.6 & NS & NS & NS & 0.07 \\
\hline \multicolumn{12}{|c|}{ Pancreatic specificactivity, UI·mg protein ${ }^{-1}$} \\
\hline Chymotrypsin & $260^{\mathrm{a}}$ & $189^{\mathrm{b}}$ & $133^{\mathrm{b}}$ & 168 & 172 & 208 & 228 & 0.01 & NS & NS & 11.10 \\
\hline Trypsin & $26^{\mathrm{a}}$ & $27^{\mathrm{a}}$ & $32^{\mathrm{b}}$ & $31^{\mathrm{A}}$ & $25^{\mathrm{B}}$ & $24^{\mathrm{B}}$ & $32^{\mathrm{A}}$ & 0.05 & 0.05 & NS & 0.90 \\
\hline
\end{tabular}

$* \mathrm{C}=$ Casein diet (reference diet), $\mathrm{SM}=$ sesame meal diet, $\mathrm{SBM}=$ soybean meal diet. $\mathrm{D}=\mathrm{Diet}$ effect, $\mathrm{H}=\mathrm{Hour}$ after feeding effect, $\mathrm{D} * \mathrm{H}=$ Diet $*$ hour after feeding interaction. SEM $=$ Standard Error of Mean. ${ }^{\mathrm{a}, \mathrm{b}}$ Values with different superscripts between diets in the same raw are significantly different $(\mathrm{p}<0.05) .{ }^{\mathrm{AB}}$ Values with different superscripts between hours after feeding in the same raw are significantly different $(\mathrm{p}<0.05)$. NS = Non Significant 
Table 5. Morphology of intestinal villi of duodenum, jejunum and ileum of piglets fed with C, SM and SBM diets

\begin{tabular}{|c|c|c|c|c|c|}
\hline \multirow[b]{2}{*}{ Morphology } & \multicolumn{3}{|c|}{ Experimental diets* } & \multirow[b]{2}{*}{$\mathrm{p}<$} & \multirow[b]{2}{*}{ SEM } \\
\hline & $\mathrm{C}$ & SM & SBM & & \\
\hline \multicolumn{6}{|l|}{ Duodenum } \\
\hline Villi height $(\mu \mathrm{m})$ & 409.00 & 411.00 & 418.00 & NS & 27.60 \\
\hline Crypt depth $(\mu \mathrm{m})$ & 152.00 & 139.00 & 180.00 & NS & 11.50 \\
\hline \multicolumn{6}{|l|}{ Jejunum } \\
\hline Villi height $(\mu \mathrm{m})$ & $404.00^{\mathrm{a}}$ & $424.00^{\mathrm{a}}$ & $203.00^{\mathrm{b}}$ & 0.05 & 21.70 \\
\hline Crypt depth $(\mu \mathrm{m})$ & 156.00 & 143.00 & 204.00 & NS & 8.00 \\
\hline \multicolumn{6}{|l|}{ Ileum } \\
\hline Villi height $(\mu \mathrm{m})$ & 268.00 & 352.00 & 278.00 & NS & 40.70 \\
\hline Crypt depth $(\mu \mathrm{m})$ & 192.00 & 153.00 & 157.00 & NS & 16.70 \\
\hline \multicolumn{6}{|l|}{ Diarrhea } \\
\hline Fecal score & 0.38 & 0.52 & 0.59 & NS & 0.17 \\
\hline Diarrhea incidence (day) & 2.50 & 5.30 & 4.50 & NS & 0.97 \\
\hline
\end{tabular}

Intestinal morphology results are described in Table 5. Villus height and duodenal and ileal crypt depths were not affected by dietary protein source $(\mathrm{p}>0.05)$. The average jejunal villus length was longer in piglets receiving the SM diet $(p<0.05)$ than in piglets receiving the SBM and C diets. Jejunal crypt depth was equal (p> 0.05) among all experimental groups.

The dietary protein source did not affect the diarrhea incidence or the fecal score $(\mathrm{p}>0.05)$.

\section{DISCUSSION}

Stomach and small intestine weight was greater in piglets fed a vegetable protein diet than in those fed the casein diet. This may be caused by the higher fiber content and the presence of the trypsin inhibitor in vegetable proteins, as previously reported by Csaky and Fekete (2004). Furthermore, the experimental diets did not cause any detrimental effect on visceral weight of the experimental animals, which is similar to findings in other studies (Csaky and Fekete, 2004; Reis de Souza et al., 2007; 2012; Opapeju et al., 2008).

Stomach digesta $\mathrm{pH}$ values found, indicate that the diet modulates the chemical characteristics of gastric secretion. The optimal stomach $\mathrm{pH}$ range for pepsin protein digestion (Makkink et al., 1994; Morales et al., 2012; Heo et al., 2013) is 2 to 4. The lowest gastric acidic content was observed in piglets fed the $\mathrm{C}$ diet and it is likely caused by casein's higher buffering capacity due its greater number of amino acids with carboxylic radicals, as well as the presence of phosphate radicals (Salaun et al., 2005). Sesame meal also showed a high buffering capacity, which is derived from its high concentration of arginine and cysteine and prevented a drastic $\mathrm{pH}$ decrease in the stomach. Soybean meal showed comparatively less buffering capacity, probably due to its high concentration of acidic amino acids (glutamic and aspartic), as it has been demonstrated in other legumes (Al-Dabbas et al., 2010). Duodenal digesta $\mathrm{pH}$ values observed in piglets in the present study (average $\mathrm{pH}=5.7$ ), showed that the acidic chyme was neutralized to protect the intestinal mucosa and prevent denaturation from digestive enzymes. The pancreas also contributes to duodenal $\mathrm{pH}$ by secreting bicarbonate ions into the duodenum under the influence of the hormones Cholecystokinin (CCK) and secretin (Clemente and Domoney, 2006). In the present study, the progressive increase of $\mathrm{pH}$ from the stomach to the ileum allowed the proper conditions for enzymatic activity in the small intestine (Makkink et al., 1994; Morales et al., 2012).

The decreased activity of trypsin in the first $9 \mathrm{~h}$ after feeding was a consequence of decrease in the quantity of protein present in the gastrointestinal tract. Makkink et al. (1994) observed that the secretion of proteolytic enzymes from the pancreas is directly proportional to the presence of protein in the gastrointestinal tract, which decreases over time after feeding. However, the increase in specific activity of trypsin (expressed as IU.mg protein ${ }^{-1}$ ) observed at $12 \mathrm{~h}$ after feeding, probably due the decrease of pancreatic protein concentration in absence of feed (fasting) in the gastrointestinal tract (Nagy et al., 1989). Enzyme and hormone secretion from the digestive tract in weaned piglets depends on the degree of gastrointestinal stimulation from the feed ingested (Cranwell, 1995). 
Other factors modulating digestive tract function are the protein source quality, protein digestibility, feed processing and the presence of ANF (Makkink et al., 1994; Hermes et al., 2009). Findings in the present study indicate that ANF is one of the most important factors that may explain the influence of the protein source on digestive enzyme activity and morphology of intestinal mucosa. We suspect that the higher trypsin specific activity in piglets fed SBM is caused by the trypsin inhibitor factor in soybean meal, which in turn may stimulate CCK hormone secretion from intestinal cells, resulting in greater pancreatic trypsin synthesis and secretion through negative feedback mechanisms (Owyang et al., 1994). This negative feedback loop mediated by $\mathrm{CCK}$ has been reported in rats, pigs, calves and humans (Clemente and Domoney, 2006; Woyengo et al., 2009).

The chymotrypsin specific activity in piglets fed SM and SBM was lower than in piglets fed C, a finding possibly resulting from the presence of phytic acid. Phytic acid may induce ionic bonding to the basic amino acids in proteins such as chymotrypsin (lysine and arginine) at the $\mathrm{pH}$ present in the small intestine (5.7 to 7.6) (Adeola and Sands, 2003).

Previous studies have revealed the presence of certain allergenic proteins (glycinin and $\beta$-conglycinin), lectins and trypsin inhibitor in soybean meal (Csaky and Fekete, 2004; Purushotham et al., 2007), all of which can decrease jejunal villus height, as observed in piglets receiving SBM diet. Li et al. (1991) and Csaky and Fekete (2004) have observed similar effects in weaned piglets fed soybean meal diets.

Zhan et al. (2008) and Shan et al. (2012) observed that dietary supplementation of arginine improved intestinal mucosa development in weaning piglets. Sesame meal contributes to $48 \%$ more arginine than soybean meal, which may explain the larger jejunal villi observed in piglets fed SM diet. Arginine is theorized to increase enterocyte metabolism by increasing nitrogen transport in tissue proteins; it is also a substrate in multiple enzymatic pathways, including arginase, nitric oxide synthase, ARG-glycine aminotransferase and arginyl-tRNA synthetase and is a precursor for the synthesis of creatinine, proline, glutamate, polyamines and nitric oxide synthase (Wu et al., 2007).

Diarrhea incidence and associated fecal score in all piglets, regardless of diet offered, were consistent with what is commonly observed at weaning. Fecal score was similar to values observed by Opapeju et al. (2008) and Bhandari et al. (2009) at 14 days post-weaning. Diarrhea incidence in the present study was higher than that reported by Hermes et al. (2009), who used diets containing antibiotics, but fecal score did not show any relative increase. Opapeju et al. (2008) and Bhandari et al. (2009) observed fecal scores during the second week postweaning in animals fed SBM diets without antibiotics, which is similar to fecal scores reported in the present study. Zhan et al. (2008) and Grimble (2007) have reported that arginine induces nitric oxide-mediated water and electrolyte secretion, which at low levels $(0.7 \%)$ acts as an absorber and at high levels $(>1.2 \%)$ as a secretagogue; however, in the present study, the arginine level in the SM diet $(0.86 \%)$ was not high enough to induce diarrhea or increase diarrhea incidence.

\section{CONCLUSION}

A sesame meal diet fed to piglets during the weaning period did not have a negative effect on gastrointestinal tract development, digesta $\mathrm{pH}$, diarrhea incidence, fecal score, trypsin activity, or small intestine villus morphological characteristics. In addition, the higher content of crude protein, sulfur amino acids and arginine, together with the lower trypsin inhibitory activity in sesame meal compared to that of soybean meal, make it an important alternative protein source for piglets feeding during the weaning period. However, further studies about nitrogen digestibility and growth performance in piglets are needed to recommend the use of sesame meal in starter diets.

\section{ACKNOWLEDGEMENT}

Partially funded by SEP-CONACYT Grant No. 179898 CB-2012-01. The authors gratefully acknowledge to Dipasa Internacional de México, S.A. de C.V. for providing the sesame meal for the experiment.

\section{REFERENCES}

Adeola, O. and J.S. Sands, 2003. Does supplemental dietary microbial phytase improve amino acid utilization? A perspective that it does not. J. Anim. Sci., 81: E78-E85.

Al-Dabbas, M.M., K. Al-Ismail, R.A. Taleb and S. Ibrahim, 2010. Acid-base buffering properties of five legumes and selected food in vitro. Am. J. Agric. Biol. Sci., 5: 154-160. DOI: 10.3844/ajabssp.2010.154.160

AOAC, 2000. Official Methods of Analysis. 17th Edn., Association of Official Analytical Chemists, Gaithersburg, MD, USA., ISBN-10: 0935584676. 
Bhandari, S.K., C.M. Nyachoti and D.O. Krause, 2009. Raw potato starch in weaned pig diets and its influence on postweaning scours and the molecular microbial ecology of the digestive tract. J. Anim. Sci., 87: 984-993. DOI: 10.2527/jas.2007-0747

CIOMS, 1985. International guiding principles for biomedical research involving animals. The development of science-based guidelines for laboratory animal care. NCBI Bookshelf.

Clemente, A. and C. Domoney, 2006. Biological significance of polymorphism in legume protease inhibitors from the Bowman-Birk family. Current Protein Peptide Sci., 7: 201-216. DOI: 10.2174/138920306777452349

Cranwell, P.D., 1995. Development of the Neonatal Gut and Enzyme Systems. In: The Neonatal Pig Development and Survival, Varley, M.A., Edr, Wallingford UK: CABI Publishing. ISBN-10: 085198925X, pp: 99-154.

Csaky, I. and S. Fekete, 2004. Soybean: Feed quality and safety. Part 2: Pathology of soybean feeding in animals. A review. Acta Veterinaria Hungarica, 52: 315-326. DOI: 10.1556/AVet.52.2004.3.7

DOF, 2001. Norma Oficial Mexicana-NOM-062-ZOO1999, Especificaciones técnicas para la producción, cuidado y uso de los animales de laboratorio. Diario Oficial de la Federación. México, D.F.

Friesen, K.G., R.D. Goodband, J.L. Nelssen, F. Blecha and D.N. Reddy et al., 1993. The effect of pre- and postweaning exposure to soybean meal on growth performance and on the immune response in the early-weaned pig. J. Anim. Sci., 71: 2089-2098. PMID: 8376233

Grimble, G.K., 2007. Adverse gastrointestinal effects of arginine and related amino acids. J. Nutrit., 137: 1693S-1701S. PMID: 17513449

Henderson, J.H., R.D. Ricker, B.A. Bidlingmeyer and C. Woodward, 2000. Rapid, accurate and reproducible HPLC analysis of amino acids. Amino acid analysis using Zorbax Eclipse AAA columns and the Agilent 1100 HPLC. Agilent technologies Part No. 5980$1193 \mathrm{E}$.

Heo, J.M., F.O. Opapeju, J.R. Pluske, J.C. Kim and D.J. Hampson et al., 2013. Gastrointestinal health and function in weaned pigs: A review of feeding strategies to control post-weaning diarrhea without using in-feed antimicrobial compounds. J. Anim. Physiol. Anim. Nutr., 97: 207-237. DOI: 10.1111/j.1439-0396.2012.01284.x
Hermes, R.G., F. Molist, M. Ywazaki, M. Nofrarias and A.G. de Segura et al., 2009. Effect of dietary level of protein and fiber on the productive performance and health status of piglets. J. Anim. Sci., 87: 35693577. DOI: $10.2527 /$ jas.2008-1241

Hummel, B.C.W., 1959. A modified spectrophotometric determination of chymotrypsin, trypsin and thrombin. Canad. J. Biochem. Physiol., 37: 13931399. PMID: 14405350

Jimoh, W.A., O.A. Fagbenro and E.O. Adeparusi, 2011. Effect of processing on some minerals, anti-nutrients and nutritional composition of sesame (Sesamum indicum) seed meals. Electronic J. Environ. Agric. Food Chem., 10:1858-1864.

Kakade, M.L., J.J. Rackis, J.E. McGhee and G. Puski, 1974. Determination of trypsin inhibitor activity of soy products: A collaborative analysis of an improved procedure. Cereal Chem., 51: 376-382. DOI: $10113 / 31302$

Lallès, J.P., P. Bosi, H. Smidt and R. Stokes, 2007. Nutritional management of gut health in pigs around weaning. Proc. Nutr. Soc., 66: 260-268. PMID: 17466106

Li, D.F., J.L. Nelssen, P.G. Reddy, F. Blecha and R.D. Klemm et al., 1991. Measuring suitability of soybean products for early-weaned pigs with immunological criteria. J. Anim. Sci., 69: 32993307. PMID: 1894566

Makkink, C.A., P.J.M. Berntsen, B.M.L. Op den Kamp, B. Kemp and M.W.A. Verstegen, 1994. Gastric protein breakdown and pancreatic enzyme activities in response to two different dietary protein sources in newly weaned pigs. J. Anim. Sci., 72: 2843-2850. PMID: 7730177

Morales, A., H. Garcia, J.E. Sanchez, B.A. Araiza and R.T. Zijlstra et al., 2012. Apparent ileal amino acid digestibility and activities of trypsin and chymotrypsin in pigs fed sorghum-soybean meal diets supplemented with a microbial phytase. Anim. Feed Sci. Technol., 172: 247-251. DOI: 10.1016/j.anifeedsci.2012.01.007

Nabuurs, M.J.A., A. Hoogendoorn, E.J. Ven der Molen and L.M. Van Osta, 1993. Villus height and crypy depth in weaned and unweaned pigs, reared under various circumstances in the Netherlands. Res. Vet. Sci., 55: 78-84. PMID: 8378616

Nagy, I., A. Pap and V. Varro, 1989. Time-course of changes in pancreatic and enzyme composition in rats during starvation size. Int. J. Pancreatol., 5: 3545. DOI: 10.1007/BF02925696 
NRC, 1998. Nutrients Requirements of Swine. 10th Edn National Academy Press, Washington, D.C., ISBN10: 0309059933, pp: 116.

Opapeju, F.O., D.O. Krause, R.L. Payne, M. Rademacher and C.M. Nyachoti, 2009. Effect of dietary protein level on growth performance, indicators of enteric health and gastrointestinal microbial ecology of weaned pigs induced with postweaning colibacillosis. J. Anim. Sci., 87: 26352643. DOI: $10.2527 /$ jas.2008-1310

Opapeju, F.O., M. Rademacher, G. Blank and C.M. Nyachoti, 2008. Effect of low-protein amino acidsupplemented diets on the growth performance, gut morphology, organ weights and digesta characteristics of weaned pigs. Animal, 2: 14571464. DOI: $10.1017 / \mathrm{S} 175173110800270 \mathrm{X}$

Owyang, C.H., 1994. Negative feedback control of exocrine pancreatic secretion: Role of cholecystokinin and cholinergic pathway. J. Nutr., 124: 1321S-1326S. PMID: 7914921

Palacios, M.F., R.A. Easter, K.T. Soltwedel, C.M. Parsons and M.W. Douglas et al., 2004. Effect of soybean variety and processing on growth performance of young chicks and pigs. J. Anim. Sci., 82: 1108-1114. PMID: 15080333

Purushotham, B., P.M. Radhakrishna and B.S. Sherigara, 2007. Effects of steam conditioning and extrusion temperature on some anti-nutritional factors of soyabean (Glycine max) for pet food applications. Am. J. Anim. Vet. Sci., 2: 1-5. DOI: 10.3844/ajavsp.2007.1.5

Reboud, J.P., A.A. Ben and P. Desnuelle, 1962. Variations de la teneur en enzymes de pancreas de rat en function de la composition des régimes. Biochim. Biophys. Acta, 58: 326-327. PMID: 14037470

Reis de Souza, T.C., L.G. Mariscal and G.K. Escobar, 2010. Algunos factores fisiológicos y nutricionales que afectan la incidencia de diarreas posdestete en lechones. Vet. México, 41: 275-288.

Reis de Souza, T.C., L.G. Mariscal, G.K. Escobar, B.A. Aguilera and B.A. Magné, 2012. Cambios nutrimentales en el lechón y desarrollo morfofisiológico de su aparato digestivo. Vet. México, 43: 155-173.

Reis de Souza, T.C., M.A.B. Aguilera, A.B. Aguilera, L.G. Mariscal and C.M.J. Guerrero, 2007. Morfología del tracto digestivo de lechones alimentados con dietas con aislado o concentrado de proteínas de soya. Arch. Latinoamericanos Produc. Anim., 15: 134-140.
Salaun, F., B. Mietton and F. Gaucheron, 2005. Buffering capacity of dairy products. Int. Dairy J., 15: 95-109. DOI: 10.1016/j.idairyj.2004.06.007

SAS, 2008. SAS/STAT ${ }^{\circledR} 9.2$ User's Guide. SAS Institute Inc., Cary, NC.

Shan, Y., A. Shan, J. Li and Ch. Zhou, 2012. Dietary supplementation of arginine and glutamine enhances the growth and intestinal mucosa development of weaned piglets. Livestock Sci., 150: 369-373. DOI: 10.1016/j.livsci.2012.10.006.

Steel, R.G.D., J.H. Torrie and D.A. Dickey, 1997. Principles and Procedures of Statistics: A Biometrical Approach. 3rd Edn., McGraw-Hill Book Co., New York, US., ISBN-10: 0070610282.

Vaintraub, I.A. and N.A. Lapteva, 1988. Colorimetric determination of phytate in unpurified extracts of seeds and the products of their processing. Analytical Biochem., 15: 227-230. PMID: 3245569

Van Soest, P.J., J. Robertson and B.A. Lewis, 1991. Methods for dietary fiber neutral detergent fiber and nonstarch polysaccharides in relation to animal nutrition. J. Dairy Sci., 74: 3583-3594. PMID: 1660498

Vente-Spreeuwenberg, M.A., J.M. Verdonk, H.R. Gaskins and M.W.A. Verstegen, 2001. Small intestine epithelial barrier function is compromised in pigs with low feed intake at weaning. J. Nutr., 131: 1520-1527. PMID: 11340110

Woyengo, T.A., A.J. Cowieson, O. Adeola and C.M. Nyachoti, 2009. Ileal digestibility and endogenous flow of minerals and amino acids: Responses to dietary phytic acid in piglets. British J. Nut., 102: 428-433. DOI: 10.1017/S0007114508184719

Wu, W., F.W. Bazer, T.A. Davis, L.A. Jaeger and G.A. Johnson et al., 2007. Important roles for the arginine family of amino acids in swine nutrition and production. Livestock Sci., 112: 8-22. DOI: 10.1016/j.livsci.2007.07.003

Zhan, Z., D. Ou, X. Piao, S.W. Kim and Y. Liu et al., 2008. Dietary arginine supplementation affects microvascular development in the small intestine of early-weaned pigs. J. Nutr., 138: 1304-1309. PMID: 18567752 